University of Nebraska - Lincoln

DigitalCommons@University of Nebraska - Lincoln

Faculty Publications from the Harold W. Manter Laboratory of Parasitology

$10-2009$

\title{
Eimeria spp. (Apicomplexa: Eimeriidae) from the Plateau Pika, Ochotona curzoniae, from Haibei Area, Qinghai Province, China, with the Description of Two New Species
}

\author{
Yi-Fan Cao \\ Qinghai Provincial Consultative Station of Animal and Veterinary Science and Technology \\ Run-Roung Ye \\ Qinghai Provincial Consultative Station of Animal and Veterinary Science and Technology \\ Jian-Hua Wu \\ Qinghai Provincial Consultative Station of Animal and Veterinary Science and Technology \\ Jiang-Hui Bian \\ Chinese Academy of Sciences, bjh@nwipb.ac.cn \\ Donald W. Duszynski \\ University of New Mexico, eimeria@unm.edu
}

Follow this and additional works at: https://digitalcommons.unl.edu/parasitologyfacpubs

Part of the Parasitology Commons

Cao, Yi-Fan; Ye, Run-Roung; Wu, Jian-Hua; Bian, Jiang-Hui; and Duszynski, Donald W., "Eimeria spp. (Apicomplexa: Eimeriidae) from the Plateau Pika, Ochotona curzoniae, from Haibei Area, Qinghai Province, China, with the Description of Two New Species" (2009). Faculty Publications from the Harold W. Manter Laboratory of Parasitology. 131.

https://digitalcommons.unl.edu/parasitologyfacpubs/131

This Article is brought to you for free and open access by the Parasitology, Harold W. Manter Laboratory of at DigitalCommons@University of Nebraska - Lincoln. It has been accepted for inclusion in Faculty Publications from the Harold W. Manter Laboratory of Parasitology by an authorized administrator of DigitalCommons@University of Nebraska - Lincoln. 


\title{
EIMERIA SPP. (APICOMPLEXA: EIMERIIDAE) FROM THE PLATEAU PIKA, OCHOTONA CURZONIAE, FROM HAIBEI AREA, QINGHAI PROVINCE, CHINA, WITH THE DESCRIPTION OF TWO NEW SPECIES
}

\author{
Cao Yi-Fan, Ye Run-Roung, Wu Jian-Hua*, Bian Jiang-Hui†, and Donald W. Duszynski $\ddagger$ \\ Key Laboratory of Adaptation and Evolution of Plateau Biota, Northwest Institute of Plateau Biology, Chinese Academy of Sciences, Xining 81000 , \\ China.e-mail: bjh@nwipb.ac.cn
}

\begin{abstract}
Fifty-two fecal samples from the Plateau pika, Ochotona curzoniae, collected in the Haibei Area, Qinghai Province, China, were examined for the presence of coccidia (Apicomplexa: Eimeriidae). Five distinct morphotypes, all Eimeria species, were distinguished based on the structure of their sporulated oocysts. Three of these included Eimeria banffensis, Eimeria calentinei, and Eimeria cryptobarretti, all of which have been described previously from other Ochotona species. We also studied 2 morphotypes that we feel have sufficient qualitative and quantitative characters to distinguish them from all previously described species; herein, we identify them as putative new species. Eimeria qinghaiensis n.sp. was found in 18/52 (35\%) O. curzoniae. It has ovoidal oocysts with a $3-$ layered wall, with a rough outermost layer and a micropyle, $\sim 9 \mu \mathrm{m}$ wide. Sporulated oocysts are $37.2 \times 27.2(34-41 \times 24-32) \mu \mathrm{m} ; 1$ polar granule is present, but an oocyst residuum is absent. Sporocysts are ovoidal, $16.6 \times 9.8(14-19 \times 9-11) \mu \mathrm{m}$ with a Stieda body; sporocyst residuum and sporozoites have 2 refractile bodies. Eimeria haibeiensis n. sp. was found in 21/52 (40\%) pikas. It has ellipsoidal to ovoidal oocysts, with a 2-layered smooth wall and a micropyle, $3.9 \mu \mathrm{m}$ wide. Oocysts are $22.2 \times 16.2(20-24 \times 15-18) \mu \mathrm{m}$; polar granule and oocyst residuum are both absent. Sporocysts are ovoidal, $11.6 \times 6.6(10-13 \times 5-7) \mu \mathrm{m}$, with a Stieda body; sporocyst residuum and sporozoites each have 2 refractile bodies, 1 at each end. The 5 eimerian species we discovered in $O$. curzoniae in China all represent new host and locality records.
\end{abstract}

Pikas are Holarctic lagomorphs composed of a single genus, Ochotona, with about 25 species (Wilson and Reeder, 2005). The majority of species are found in Asia, mainly in the QinghaiTibetan Plateau (West China) region, but also in Afghanistan, Burma, India, Iran, Japan, Kazakhstan, Korea, Nepal, Pakistan, and Russia, whereas only 2 species are found in North America (Chapman and Flux, 1990; Yu et al., 2000; Wilson and Reeder, 2005). Currently, 18 coccidia species (16 Eimeria, 2 Isospora) are described from 6 Ochotona species (Lynch et al., 2007). Plateau pika, Ochotona curzoniae Hudgson, are a key species on the Qinghai-Tibetan Plateau, where it plays an important role in biodiversity of the ecosystem (Smith and Foggin, 1999). Several studies have examined ectoparasite and parasitic helminth infections of the Plateau pika (Zhang, 1991; Cao and Ye, 1998; Ding et al., 1999; Wang et al., 2003; Ci et al., 2008), but, to our knowledge, there are no studies on the intestinal coccidian parasite infections from $O$. curzoniae.

\section{MATERIALS AND METHODS}

From 15 to 18 September 2008, 52 Plateau pikas, O. curzoniae Hodgson, 1858, were collected from the Haibei Alpine Meadow Ecosystem Research Station (Fig. 1), Chinese Academy of Sciences $\left(37^{\circ} 36^{\prime} \mathrm{N}, 101^{\circ} 18^{\prime} \mathrm{E}\right.$; alt. 3,205 m), approximately $155 \mathrm{~km}$ north of Xining, the capital of Qinghai Province, People's Republic of China (PRC). This habitat is an alpine meadow dominated by Kobrsia pygmaea.

All hosts were live-trapped and killed within a few hours of capture. The intestinal tract was removed, and feces from the colon and cecum were placed in a $20-\mathrm{ml}$ plastic container with a screw cap and mixed/diluted 1:5 with $2.5 \%(\mathrm{w} / \mathrm{v})$ aqueous potassium dichromate $\left(\mathrm{K}_{2} \mathrm{Cr}_{2} \mathrm{O}_{7}\right)$ solution. Fecal samples were then spread out in Petri dishes and covered for 6 days at $25 \mathrm{C}$ to allow time for oocyst sporulation, after which they were examined by coverslip flotation using a saturated salt solution. Following the

Received 11 February 2009; revised 3 April 2009, 28 April 2009; accepted 30 April 2009.

* Qinghai Provincial Consultative Station of Animal and Veterinary Science and Technology, Xining 810008, China.

$\uparrow$ To whom correspondence should be addressed.

\$Department of Biology, University of New Mexico, Albuquerque, New Mexico 87131

DOI: $10.1645 / G E-2063.1$ guidelines of Duszynski and Wilber (1997), oocysts were measured and photographed using an oil immersion lens on a Digital Bio-microscope DMBS-223IPL-5. All measurements are in $\mu \mathrm{m}$, with the ranges in parentheses following the means. Standardized abbreviations for structural characteristics of both oocysts and sporocysts follow Wilber et al (1998): oocyst wall (OW), oocyst length (L) and width (W) and their ranges and ratios $(\mathrm{L} / \mathrm{W})$, micropyle $(\mathrm{M})$, micropyle cap $(\mathrm{MC})$, oocyst residuum (OR), polar granule (PG), sporocyst residuum (SR), Stieda body (SB), substieda body (SSB), parastieda body (PSB), refractile body (RB), sporozoite (SZ), and nucleus (N). Skins and skulls of symbiotype hosts (Frey et al., 1992) are preserved in the Qinghai-Tibet Plateau Biological Specimen Museum (QPBSM), and photosyntypes (Duszynski, 1999) of sporulated oocysts are deposited in the Key Laboratory of Adaptation and Evolution of Plateau Biota (KLAEPB).

\section{RESULTS}

Oocysts of 5 species of Eimeria, including 2 new species and 3 species previously reported from other Ochotona species, were found in the feces of $O$. curzoniae, as described below.

\section{DESCRIPTIONS}

\section{Eimeria qinghaiensis $\mathbf{n}$. sp.}

(Figs. 2-4, 12)

Diagnosis: Sporulated oocysts ovoidal. OW with 3 layers; outer layer rough, with prominent, sunken $M$ (Fig. 2); inner walls smooth with $M$ barely visible (Fig. 3 ), intact walls $\sim 2$ thick. $\mathrm{L} \times \mathrm{W}(\mathrm{N}=70): 37.2 \times 27.2$ (34 $41 \times 24-32)$; L/W: 1.4 (1.1-1.6). M and PG present, 9 (7.5-12.1) and 2.6 (2.4-3.2) wide, respectively (Fig. 4). OR absent. Sporocysts ovoidal, L $\times \mathrm{W}(\mathrm{N}=50) ; 16.6 \times 9.8(14-19 \times 9-11) . \mathrm{L} / \mathrm{W}: 1.7(1.4-1.9)$. SB present at pointed end of sporocyst. SSB and PSB both absent. SR present, a compact spheroidal mass of tiny granules, $6.8 \times 5.7(5-9 \times 5-7)$. SZ with an anterior RB, $2 \times 3(2-4 \times 2-3)$ and a posterior RB, $6 \times 4(4-6 \times 3-4)$. $\mathrm{N}$ visible between $\mathrm{RB}$.

\section{Taxonomic summary}

Type host: Ochotona curzoniae Hudgson, 1858, Plateau pika.

Other hosts: None to date.

Type locality: Asia: People's Republic of China: Qinghai Province, Haibei Alpine Meadow Ecosystem Research Station, Chinese Academy of Sciences, $37^{\circ} 36^{\prime} \mathrm{N}, 101^{\circ} 18^{\prime} \mathrm{E}$; altitude $3,205 \mathrm{~m}$.

Prevalence: 18/52 (35\%) O. curzoniae in China. 


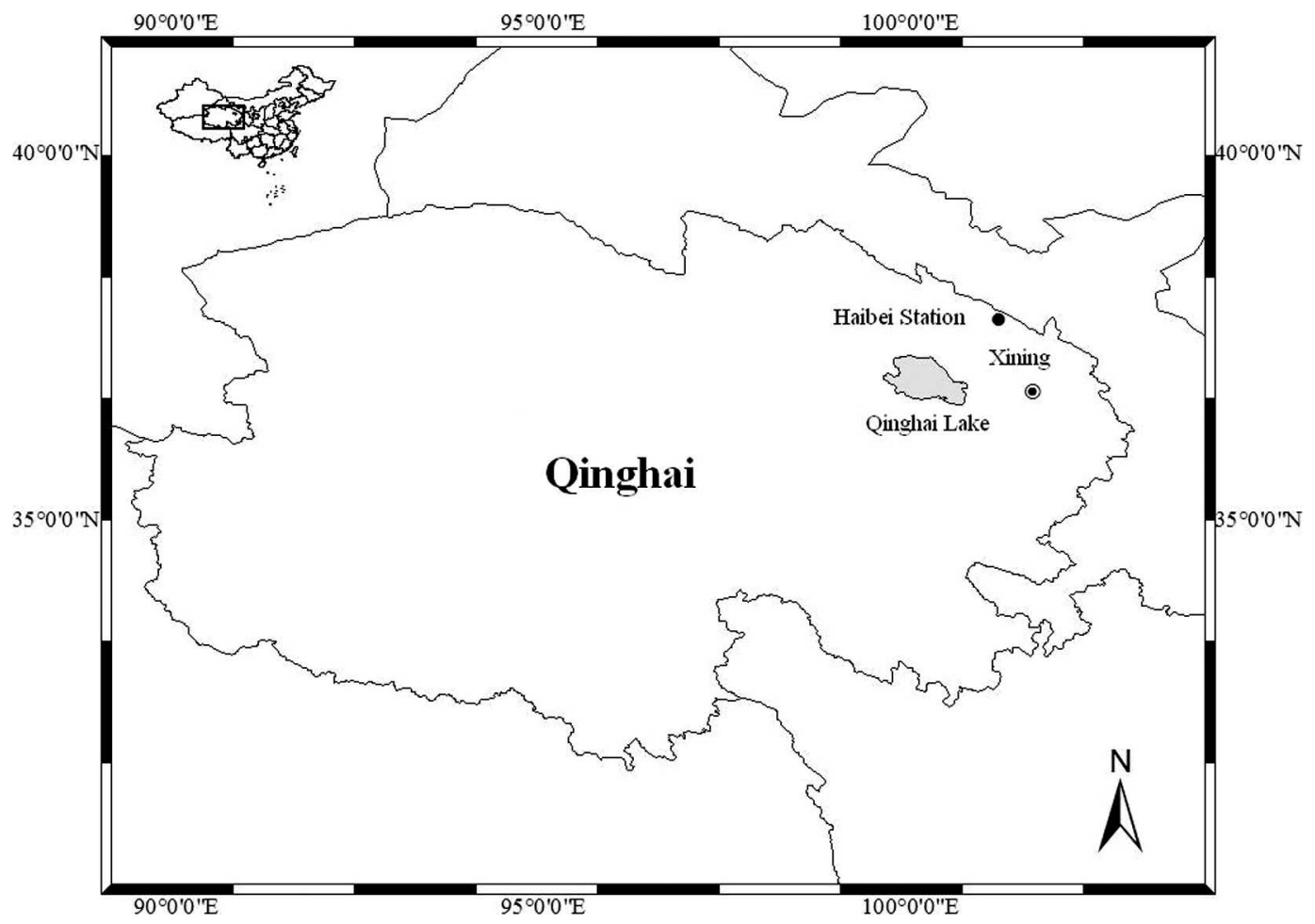

Figure 1. Map showing the collecting location of the $O$. curzoniae.

Material deposited: Skull and skin of the symbiotype host are preserved in the QPBSM, as QPBSM No. 0006869, female, 15 September 2008. Photosyntypes of sporulated oocysts in the KLAEPB, No. 08091.

Etymology: The nomen triviale is derived from the name of the province in the PRC in which the host animal was collected and -ensis (L., belonging to).

\section{Remarks}

Mensural features of the new species are similar in size to, but slightly larger than those of, Emeria klondikensis described from Ochotona collaris in the Yukon Territory, Canada (Hobbs and Samuel, 1974) for both their oocysts, $37.2 \times 27.2(34-41 \times 24-32)$ versus $35.2 \times 24.6(32-38 \times 23-36)$, respectively and sporocysts, $16.6 \times 9.8(14-19 \times 9-11)$ versus $15.5 \times 9.2$ $(14-16 \times 8-10)$, respectively. Qualitative features also are similar with OR, PG, and SB present in both descriptions. However, there is 1 distinct structural difference between the oocysts we found and those of $E$. klondikensis (Duszynski, 1974; Hobbs and Samuel, 1974; Lynch et al., 2007), and that is the part of the oocyst wall with the M. In all previous descriptions, line drawings, and photomicrographs, the $\mathrm{M}$ on the oocysts of E. klondikensis is on a distinct elevated structure that surrounds the M, separating it from the oocyst wall per se. The $\mathrm{M}$ on the oocysts we saw, and that we describe here as new, is a distinct part of the outermost OW and slightly depressed in it (see Fig. 2). We believe this unique difference is sufficient to separate it from E. klondikensis.

\section{Eimeria haibeiensis n. sp.}

(Fig. 5, 13)

Diagnosis: Sporulated oocysts, ellipsoidal to ovoidal (Fig. 5, 13). OW smooth, composed of 2 layers, $\sim 2$ thick. M present, $\sim 3.9(3.5-4.5)$ wide. $\mathrm{L}$ $\times \mathrm{W}(\mathrm{N}=38), 22.2 \times 16.2(20-24 \times 15-18) . \mathrm{L} / \mathrm{W} 1.4(1.3-1.6) . \mathrm{PG}$ and OR both absent. Sporocysts ovoidal, $\mathrm{L} \times \mathrm{W}(\mathrm{N}=38), 11.6 \times 6.6(10-13$ $\times 5-7) ; \mathrm{L} / \mathrm{W}: 1.8$ (1.4-2.4). SB present. SSB and PSB both absent. SR present as compact mass of granules. Two RB present in each SZ, 1 posterior and 1 usually anterior to $\mathrm{N}$.

\section{Taxonomic summary}

Type host: Ochotona curzoniae Hudgson, 1858, Plateau pika. Other hosts: None to date.
Type locality: Asia: People's Republic of China: Qinghai Province, Haibei Alpine Meadow Ecosystem Research Station, Chinese Academy of Sciences, $37^{\circ} 36^{\prime} \mathrm{N}, 101^{\circ} 18^{\prime} \mathrm{E}$; altitude 3,205 m.

Geographic distribution: Asia: People's Republic of China: Qinghai Province.

Prevalence: 21/52 (40\%) O. curzoniae in China.

Material deposited: Skull and skin of the symbiotype host are preserved in the QPBSM, as QPBSM No. 0006872, male, 16 September 2008. Photosyntype of a sporulated oocyst in the KLAEPB, No. 08097.

Etymology: The nomen triviale is derived from the name of the Research Station in the PRC in which the host animal was collected and -ensis (L., belonging to).

\section{Remarks}

This species somewhat resembles Eimeria barretti, first described from Ochotona princeps in Alberta, Canada (Lepp et al., 1972) and later reported from $O$. collaris from the Yukon Territory, Canada (Hobbs and Samuel, 1974). However, even though W. M. Samuel is an author on both papers, there are several discrepancies between the description and line drawing in the original description (see Fig. 2 of Lepp et al., 1972) and the description, line drawing, and photomicrograph in their second report of this eimerian (see Figs. 4 and 8 of Hobbs and Samuel, 1974).

In their original description of E. barretti, Lepp et al. (1972) archived a line drawing of a sporulated oocyst (their Fig. 2) that is slightly ellipsoidal and slightly flattened on 1 end, but did not show either an M or an MC. However, in their written description they stated, "The micropyle was characterized by a thinning of the oocyst wall and was 5-7 $\mu$ in diameter. A micropyle cap about 3 by $3 \mu$ was present in a few oocysts." And, "The oocyst wall was smooth, approximately $3 \mu$ thick." They also said that a prominent PG, $\sim 4 \mu \mathrm{m}$, was present in sporulated oocysts. Mensural data for their oocysts and sporocysts were $32.9 \times 23.8(27-36 \times 21-27)$ with $\mathrm{L} /$ $\mathrm{W}=1.4(1.2-1.6)$ and $12.6 \times 8.8(9-15 \times 6-12)$ with $\mathrm{L} / \mathrm{W}=1.5(1.3-1.7)$, respectively.

In their redescription of E. barretti, however, Hobbs and Samuel (1974) reported the oocysts they measured were $29.0 \times 20.1(23-32 \times 17-24)$, with $\mathrm{L} / \mathrm{W}=1.4(1.2-1.6)$ and sporocysts $14.5 \times 7.6(12-20 \times 7-8)$, with $\mathrm{L} /$ $\mathrm{W}=1.9(1.6-2.5)$. They also stated that a PG was absent. Finally, their line drawing (their Fig. 4) showed a distinct M, which their description said was "indistinct." Moreover, they did not mention the presence of a 

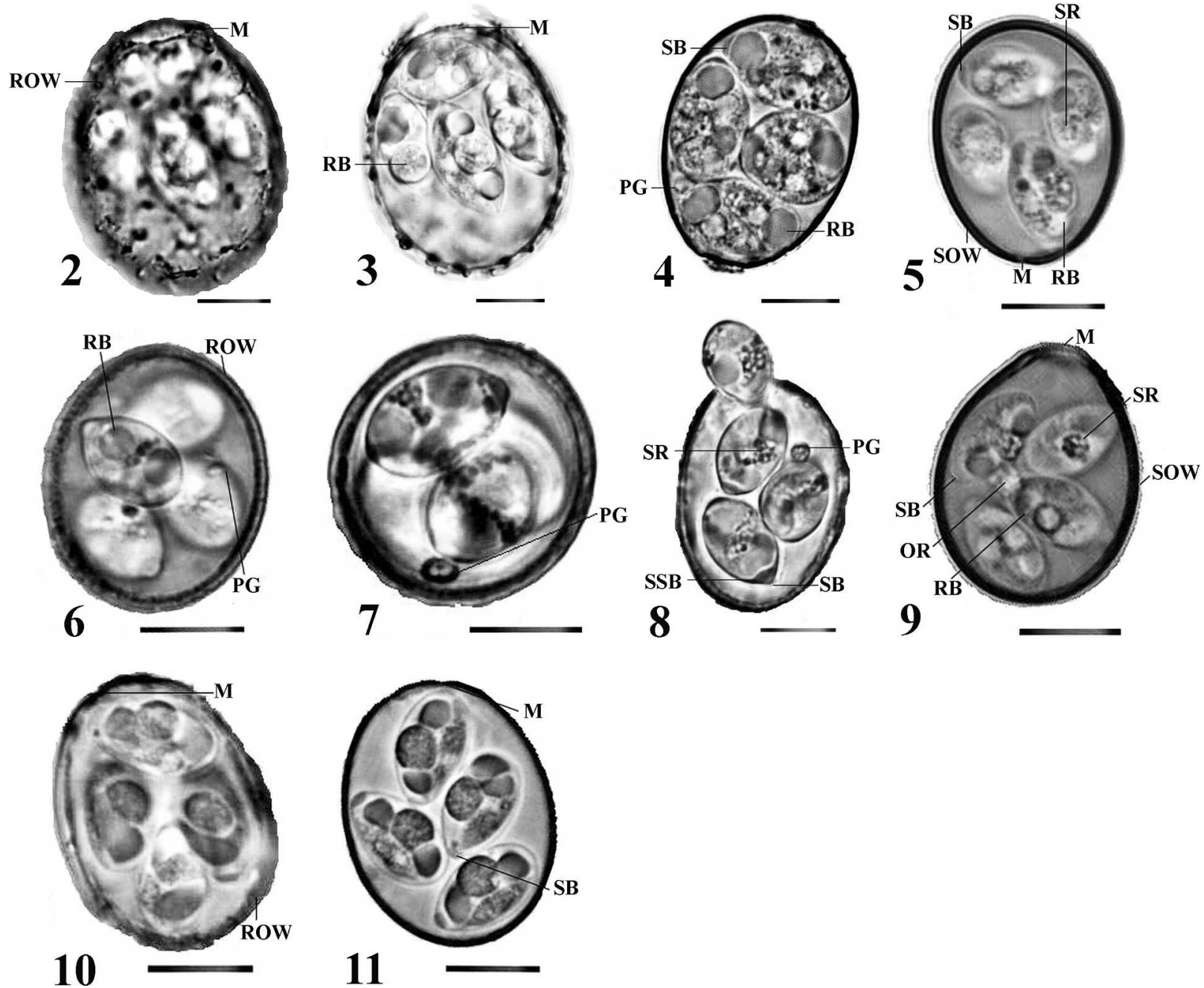

Figures 2-11. Photomicrographs of sporulated oocysts collected from the pika, O. curzoniae from China. (2-4) E. qinghaensis. (5) E. haibeinsis. (6-8) E. banffensis. (9) E. calentinei. (10-11) E. cryptobarretti. Scale bar $=10 \mu \mathrm{m}$ on all figures. M, micropyle; ROW, rough outer oocyst wall; SOW, smooth outer oocyst wall; OR, oocyst residuum; SR, sporocyst residuum; SB, Stieda body; SSB, sub-Stieda body; PG, polar granule; RB, refractile body of sporozoite.

MC, and their photomicrograph (their Fig. 8) was distinctly ellipsoidal versus the "slightly ovoid" reported by Lepp et al. (1972). Given these discrepancies, it seems to us that Hobbs and Samuel (1974) would have been prudent to give the form they called $E$. barretti a new species name, rather than confuse the mensural parameters that define the original $E$. barretti (Lepp et al., 1972)

The morphology of $E$. haibeiensis from $O$. curzoniae is similar to the description provided by Hobbs and Samuel (1974) from O. collaris. However, the oocyst and sporocyst dimensions, the absence of both OR and $\mathrm{PG}$, and the $\mathrm{L} / \mathrm{W}$ ratios of both oocysts and sporocysts give the form we describe here a sufficiently unique suite of characters that we feel justifies our describing it as a new species.

\section{REDESCRIPTION}

Eimeria banffensis Lepp, Todd, and Samuel, 1973 (Figs. 6-8)

Diagnosis: Sporulated oocysts subspheroidal (Fig. 6) to ellipsoidal (Fig. 8), or could be misinterpreted as spheroidal if viewed on end (Fig. 7). OW of uniform thickness, $\sim 2$, consisting of 2 layers; outer is rough and lightly sculptured, inner is smooth. $\mathrm{L} \times \mathrm{W}(\mathrm{N}=80): 25.6 \times 21.2(21-29 \times$ 14.5-28). L/W: $1.2(1.1-1.9)$. $\mathrm{M}$ and $\mathrm{OR}$ both absent. PG present $(\mathrm{N}=$ $30), 2.4 \times 1.7(1.5-3.5 \times 0.5-2.5)$ (Figs. 6-8). Sporocysts ovoidal, $\mathrm{L} \times \mathrm{W}$
$(\mathrm{N}=60): 11.9 \times 8.3(8-15 \times 6-10) ; \mathrm{L} / \mathrm{W}: 1.4(1.2-1.7)$. SB present with closely apposed SSB (Fig. 8). PSB absent. SR present as diffused band of granules between SZ (Figs. 6-8). SZ in intact sporocysts difficult to distinguish.

\section{Taxonomic summary}

Type host: Ochotona princeps (Richardson, 1828), American pika. Other hosts: $O$. collaris, $O$. curzoniae (this study), Ochotona hyperborea.

Type locality: North America: Canada: Alberta, Banff, Jumpinground and Sibbald Creeks.

Geographic distribution: North America: Canada: Alberta, Banff, Jumpinground and Sibbald Creeks, $51^{\circ} \mathrm{N}, 115^{\circ} \mathrm{W}$; Yukon Territory, Ogilvie Mountains $64^{\circ} \mathrm{N}, 138^{\circ} \mathrm{W}$; United States: Colorado, Larimer and Clear Creek Counties; Asia: Japan, Hokkaido, Daisetzusan National Park; Russia: Siberia, Providenya Oblast, Anadyr River; People's Republic of China: Qinghai Province, Haibei Alpine Meadow Ecosystem Research Station, Chinese Academy of Sciences, $37^{\circ} 36^{\prime} \mathrm{N}, 101^{\circ} 18^{\prime} \mathrm{E}$ altitude $3,205 \mathrm{~m}$ (this study).

Prevalence: $5 / 92(5 \%) O$. collaris in Yukon Territory; 21/52 (40\%) O curzoniae in China (this study); 3/14 (21\%) O. hyperborea in Japan; 5/35 (14\%) O. hyperborea in Siberia; 40/167 (24\%) O. princeps in Colorado; 11/ $145(8 \%)$ O. princeps in Alberta. 
Material deposited: Skull and skin of the symbiotype host are preserved in the QPBSM, as QPBSM No. 0006870, male, 16 September 2008. Photosyntypes of a sporulated oocysts in the KLAEPB, No. 08094.

\section{Remarks}

This species was first described from $O$. princeps by Lepp et al. (1973). Later, it was found in other hosts, including $O$. collaris from the Yukon Territory, Canada, O. hyperborea from Japan and Russia, and $O$. princeps from Colorado, United States (see Lynch et al., 2007). The size of the sporulated oocysts of $E$. banffensis from $O$. curzoniae in China was slightly smaller than those in the original description, $25.6 \times 21.2(21-29 \times 14.5-$ $28)$ versus $29.8 \times 25.2(27-32 \times 24-28)$, respectively. However, their L/W ratios were the same (1.2). Similarly, the sporocysts we measured in our Plateau pika also were slightly smaller, $11.9 \times 8.3(8-15 \times 6-10)$ versus $13.0 \times 9.6(10-15 \times 8-12)$, respectively, but their $\mathrm{L} / \mathrm{Ws}$ were the same $(1.4$ vs. 1.35, respectively). All other qualitative features of the sporulated oocysts were identical; thus, we attribute these minor size variations to the difference between host species. Our recovery of $E$. banffensis from $O$. curzoniae in China represents new host and locality records for this parasite.

\section{Eimeria calentinei Duszynski and Brunson, 1973 (Fig. 9)}

Diagnosis: Sporulated oocysts ovoidal, widest in middle and tapering toward M (Fig. 9); OW: 2 thick, composed of 2 layers, both smooth. L $\times \mathrm{W}(\mathrm{N}=35), 25.5 \times 17.9(24-28 \times 17-21) ; \mathrm{L} / \mathrm{W}: 1.4(1.25-1.6) . \mathrm{M}$ distinct at pointed end of oocyst, 4.4 (3-6) wide. OR spheroidal, 2.9 (2-4) wide. $\mathrm{PG}$ absent. Sporocysts ovoidal. $\mathrm{L} \times \mathrm{W}(\mathrm{N}=20) ; 10.9 \times 6.5(10-12$ $\times 6-7) ; \mathrm{L} / \mathrm{W}: 1.7$ (1.5-1.9). SB present. SSB and PSB both absent. SR granular, diffuse to spheroidal (Fig. 8). One RB, large at rounded end of SZ.

\section{Taxonomic summary}

Type host: Ochotona princeps (Richardson, 1828), American pika. Other hosts: O. collaris, O. curzoniae (this study), O. hyperborea.

Type locality: North America: United States: Colorado, Larimer County, Crown Point, altitude 3,666-3,833 m.

Geographic distribution: North America: Canada: Yukon Territory, Ogilvie Mountains, $64^{\circ} \mathrm{N}, 138^{\circ} \mathrm{W}$, Alberta, $51^{\circ} \mathrm{N}, 115^{\circ} \mathrm{W}$; United States: Colorado, Clear Creek and Larimer Counties; Alaska, Yukon-Charley Rivers National Preserve; Asia: Japan, Hokkaido, Daisetzusan National Park; Russia: Siberia, Omolon River basin, Providenya Oblast; People's Republic of China: Qinghai Province, Haibei Alpine Meadow Ecosystem Research Station, Chinese Academy of Sciences, $37^{\circ} 36^{\prime} \mathrm{N}, 101^{\circ} 18^{\prime} \mathrm{E}$; altitude 3,205 $\mathrm{m}$ (this study).

Prevalence: $5 / 53(9 \%)$ O. collaris in Alaska; 8/92 (9\%) O. collaris in Yukon Territory; 21/52 (40\%) O. curzoniae in China; 2/35 (6\%) O. hyperborea in Siberia; 1/14 (7\%) O. hyperborea in Japan; 2/111 (2\%) O. princeps in Alberta; 39/167 (23\%) O. princeps in Colorado.

Material deposited: Skull and skin of the symbiotype host are preserved in the QPBSM, as QPBSM No. 0006871, male, 17 September 2008. Photosyntype of a sporulated oocyst in the KLAEPB, No. 08096.

\section{Remarks}

This species was first described from $O$. princeps by Duszynski and Brunson (1973) in Colorado, United States. Later, it was found from other hosts including $O$. collaris from the Yukon Territory, Canada, $O$. hyperborea from Japan and Russia, and $O$. princeps from Alberta, Canada (see Lynch et al., 2007). The size of the sporulated oocysts of E. calentinei from $O$. curzoniae in China was slightly smaller than those in the original description, $25.5 \times 17.9(24-28 \times 17-21)$ versus $28.5 \times 20.0(26-32 \times 18-$ 23), respectively; however, their L/W ratios were the same (1.4). Similarly, the sporocysts we measured in our Plateau pika also were slightly smaller, $10.9 \times 6.5(10-12 \times 6-7)$ versus $12.0 \times 7.4(10-14 \times 6-9)$, respectively, but their L/Ws were similar (1.6 vs. 1.7, respectively). All other qualitative features of the sporulated oocysts were identical; thus, we attribute these minor size variations to the difference between host species. Our recovery of E. calentinei from O. curzoniae in China represent both new host and locality records for this coccidium.
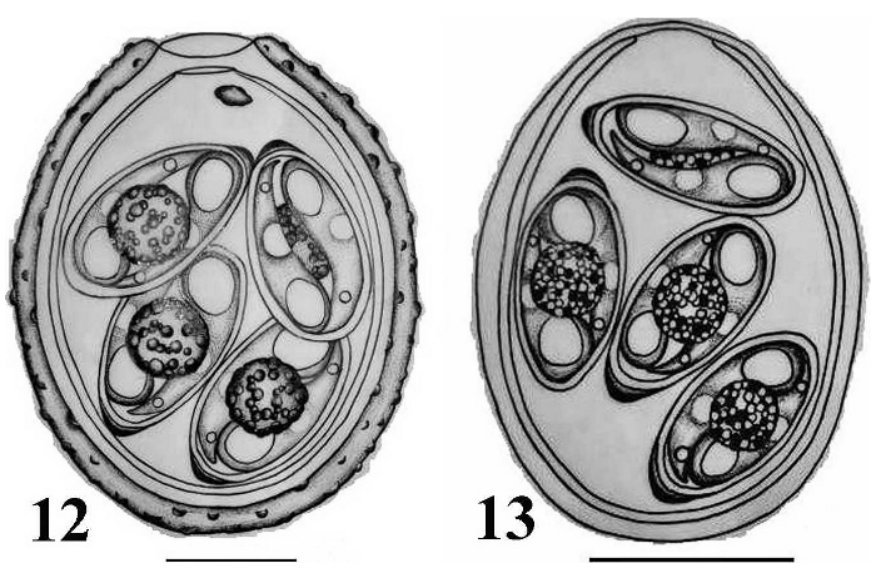

FiguRes 12-13. Line drawings of sporulated oocysts of coccidian from O. curzoniae; scale bar $=10 \mu \mathrm{m}$. (12) E. qinghaensis n.sp. (13) $E$. haibeiensis n.sp.

\section{Eimeria crytobarretti Duszynski and Brunson, 1973 (Figs. 10-11)}

Diagnosis: Sporulated oocysts ellipsoidal (Figs. 10-11). OW of 2 layers, $\sim 2$ thick; outer rough (Fig. 10), often with debris clinging to it, but inner smooth. M present, but not easily visualized in intact oocyst (Fig. 10); when outer layer separated from oocyst (Fig. 11), inner wall smooth, slightly flattened at 1 end, and thinner, giving appearance of an $\mathrm{M}$ (Fig. 11). $\mathrm{L} \times \mathrm{W}(\mathrm{N}=31): 26.0 \times 18.7(25-31 \times 16-26)$. L/W: $1.4(1.2-$ 1.7). OR and PG both absent. Sporocysts ovoidal. $\mathrm{L} \times \mathrm{W}(\mathrm{N}=25): 12.3$ $\times 7.2(11-14 \times 6-8)$. L/W: $1.7(1.5-1.85)$. SB present. SSB and PSB both absent. SR present, a spheroidal, compact mass of small granules, $\sim 4.7 \times$ $4.1(3.5-7 \times 3-5)$. SZ with $2 \mathrm{RB}$, anterior one small and a larger one posterior.

\section{Taxonomic summary}

Type host: Ochotona princeps (Richardson, 1828), American pika. Other hosts: O. collaris, O. curzoniae (this study), O. hyperborea.

Type locality: North America: United States: Colorado, Larimer County, Crown Point, altitude 3,666-3,833 m.

Geographic distribution: North America: United States: Colorado, Clear Creek and Larimer Counties; Alaska, Wrangell-St. Elias National Park, Yukon-Charley Rivers National Preserve; Asia: Russia: Siberia, Magadanskaya Oblast mouth of Kegali River; People's Republic of China: Qinghai Province, Haibei Alpine Meadow Ecosystem Research Station, Chinese Academy of Sciences, $37^{\circ} 36^{\prime} \mathrm{N}, 101^{\circ} 18^{\prime} \mathrm{E}$; altitude 3,205 m (this study).

Prevalence: $17 / 30(57 \%)$ and 90/137 (67\%) O. princeps in Colorado (Duszynski and Brunson, 1973; Duszynski, 1974; respectively); 6/53 (11\%) O. collaris in Alaska; $14 / 52$ (27\%) O. curzoniae in China; 5/35 (14\%) O. hyperborea in Siberia.

Material deposited: Skull and skin of the symbiotype host are preserved in the QPBSM, as QPBSM No. 0006873, female, 16 September 2008. Photosyntype of a sporulated oocyst in the KLAEPB, No. 08098.

\section{Remarks}

This species was first described from $O$. princeps in Colorado, United States, by Duszynski and Brunson (1973) and Duszynski (1974). Later it was found in $O$. collaris from Alaska, United States, and in $O$. hyperborea from Siberia, Russia (Lynch et al., 2007). The sporulated oocysts of $E$. crytobarretti from $O$. curzoniae were smaller than those in the original description (Duszynski and Brunson, 1973) from O. princeps, $26.0 \times 18.7$ (25-31 × 16-26) versus $29.8 \times 20.6(24-35 \times 18-22)$, respectively, but the $\mathrm{L} / \mathrm{W}$ ratios were the same (1.4). Likewise, the sporocysts we measured also were smaller, $12.3 \times 7.2(11-14 \times 6-8)$ versus $15.2 \times 8.4(13-18 \times 7-11)$, respectively, as were their L/W indices, 1.7 versus 1.8 , respectively. We attribute these minor size variations to the difference between host species. Our recovery of $E$. cryptobarretti from $O$. curzoniae in China represents new host and locality records for this parasite. 


\section{DISCUSSION}

The order Lagomorpha (pikas, rabbits, hares) consists of 2 living families with 13 genera and about 80 species; their natural range covers most of the world's land masses (Wilson and Reeder, 1992). The smallest family, Ochotonidae (pikas, mouse hares), has only 1 living genus, Ochotona, with about 25 species that are found throughout Eurasia and western North America. Lynch et al. (2007), relying mostly on the work of Yu et al. (2000), pointed out that the systematics of the genus is unstable and poorly understood. Even less is known about the parasites of these hosts, especially their coccidians. Prior to our work, only 10 papers were published documenting the presence of coccidia in pikas, and these papers described 16 Eimeria and 2 Isospora species in 6 Ochotona species (see Lynch et al., 2007, for review and summary). Here we report finding 2 new Eimeria species in $O$. curzoniae from China. To date, only 7 of 25 (28\%) pika species worldwide now have been examined for coccidia, and about 20 species are known. For several of these host species, only small numbers were sampled, so it is likely that other new Eimeria and Isospora species, especially cryptic species, exist in them (see Lynch et al., 2007).

It also is of interest where this work needs to be accomplished. Of the 25 extant pika species on Earth, 21 (84\%) are found in China, several with overlapping host ranges, but only $4(19 \%)$ of these hosts (O. curzoniae, O. dauurica, O. hyperborea, O. pallaci) have been examined for coccidia. From these 4 pika species, 17 coccidia have been described: O. curzoniae (E. qinghaensis, E. banffensis, E. calentinei, E. haibeinsis, E. cryptobarretti), $O$. dauurica (E. daurica, E. erschovi, E. metelkini, E. ochotona), O. hyperborea (E. banffensis, E. calentinei, E. circumborealis, $E$. cryptobarretti, E. klondikensis, E. princeps, E. worleyi, Isospora marquardti), and O. pallaci (E. erschovi, E. pallasi, E. shubini, Eimeria sp.). Not until the remaining Asian pika species are examined, and their coccidia discovered and described, will we be able to construct rigorous and testable hypotheses about whether their coccidia would reflect their systematics and phylogenetics. Of course, we must rely on our colleagues who study mammals to clarify and elaborate on the systematics of the host genus in the future.

\section{ACKNOWLEDGMENTS}

We thank Zheng Chang-Lin, Northwest Plateau Institute of Biology, Chinese Academy of Sciences, for his help identifying the Ochotona specimens. This work was supported by the Light of the Western Foundation Project (2009).

\section{LITERATURE CITED}

CAO, Y. F., AND R. R. YE. 1998. Survey of helminth parasitism of plateau pika. China Journal of Veterinary Science and Technology 28: 14-15.
Chapman, J. A., And J. E. C. Flux. 1990. Rabbits, hares and pikas: Status survey and conservation action plan. International Union for Conservation of Nature and Natural Resources, Gland, Switzerland, $168 \mathrm{p}$.

Ci, H. X., G. H. Lin, J. P. Su, and Y. F. CaO. 2008. Host sex and ectoparasite infections plateau pika (Ochotona curzoniae, Hodgson) on the Qinghai-Tibetan Plateau. Polish Journal of Ecology 56: $535-539$.

Ding, X. T., X. Q. He, Y. Q. CaO, and L. Dai. 1999. Reports on parasite infections on plateau pika. Sichuan Journal of Zoology 18: 34-43.

Duszynski, D. W. 1974. More information on the coccidian parasites (Protozoa: Eimeriidae) of the Colorado pika, Ochotona princeps, with a key to the species. Journal of Wildlife Diseases 10: 94-100.

. 1999. Revisiting the code: Clarifying name-bearing types for photomicrographs of Protozoa: Critical comment. Journal of Parasitology 85: 769-770.

- AND J. T. BRUnSon. 1973. Structure of the oocysts and excystation processes of four Eimeria spp. (Protozoa: Eimeriidae) from the Colorado pika, Ochotona princeps. Journal of Parasitology 59: $28-34$.

, AND P. G. WILBER. 1997. A guideline for the preparation of species descriptions in the Eimeriidae. Journal of Parasitology 83: 333-336.

Frey, J. K., T. L. Yates, D. W. Duszynski, W. L. Gannon, and S. L. GARDNER. 1992. Designation and curatorial management of type host specimens (symbiotypes) for new parasite species. Journal of Parasitology 78: 930-932.

Hobbs, R. P., AND W. M. Samuel. 1974. Coccidia (Protozoa, Eimeriidae) of the pikas Ochotona collaris, $O$. princeps, and $O$. hyperborea yesoensis. Canadian Journal of Zoology 52: 1079-1085.

Lepr, D. L., K. S. Todd, AND W. M. SAmuel. 1972. Four new species of Eimeria (Protozoa: Eimeriidae) from the pika Ochotona princeps from Alberta and O. pallasi from Kazakhstan. Journal of Protozoology 19: 192-195.

- - AND - 1973. Eimeria banffensis n. sp. (Protozoa: Eimeriidae) from the pika Ochotona princeps from Alberta. Transactions of the American Microscopical Society 92: 305-307.

Lynch., A. J., D. W. Duszynski, And J. A. Cook. 2007. Species of Coccidia (Apicomplexa: Eimeriidae) infecting pikas from Alaska, U.S.A. and Northeastern Siberia, Russia. Journal of Parasitology 93: $1230-1234$.

Smith, A. T., And J. M. Foggin. 1999. The plateau pika (Ochotona curzoniae) is a keystone species for biodiversity on the Tibetan plateau. Animal Conservation 2: 235-240.

Wang, Z. D., W. Fang, J. Ma, Y. Zhang, J. F. Cai, D. H. Han, R. Lu, AND X. Y. Zhong. 2003. Effectiveness of wild plateau pika. Chinese Qinghai Journal of Animal Veterinary Sciences 33: 2-23.

Wilber, P. G., D. W. Duszynski, S. J. Upton, R. S. Seville, and J. O. Corliss. 1998. A revision of the taxonomy and nomenclature of the Eimeria spp. (Apicomplexa: Eimeriidae) from rodents in the Tribe Marmotini (Sciuridae). Systematic Parasitology 39: 113-135.

Wilson, D. E., AND D. M. Reeder. 2005. Mammal species of the world: A taxonomic and geographic reference, 3rd ed. Johns Hopkins University Press, Baltimore, Maryland, 2,142 p.

Yu, N., C. L. Zheng, Y. P. Zhang, and W. H. Li. 2000. Molecular systematics of pikas (Genus Ochotona) inferred from mitochondrial DNA sequences. Molecular Phylogenetics and Evolution 16: 85-95.

ZHANG, G. D. 1991. Fleas,ticks and mites in plateau pika in Qinghai. Chinese Journal of Vector Biology and Control 2: 131-133. 